\title{
O caminho da nação através do rio e do tempo. Uma análise de Mia Couto (2002)
}

Fabiane Miriam Furquim ${ }^{1}$

\begin{abstract}
"Escrevo como Deus: direto mas sem pauta. Quem me ler que desentorte as palavras. Alinhada só a morte. O resto tem as duas margens da dúvida. Como eu, feito de raças cruzadas". Mia Couto
\end{abstract}

Resumo: O presente trabalho busca analisar a relação da obra de Mia Couto com os processos de desenvolvimento da nação Moçambicana após a guerra civil que assolou o país entre os anos de 1977 e 1992 . Busca-se entender como se constitui a nação num país de diversidades étnicas, onde existe uma população que por muitas vezes não se identifica com a representação de uma identidade moçambicana propriamente dita, apesar dos esforços do Estado regido pela FRELIMO em delinear estes homens. A figura do próprio Mia Couto também será analisada historicamente, visto que a sua escrita está imbricada com o seu posicionamento político. Assim, procuraremos compreender através dessa obra literária a complexa composição da nação moçambicana.

Palavras chave: Mia Couto, Nação, Moçambique.

Abstract: The present paper seeks to analyze the relation of Mia Couto's work with the processes of development of the Mozambican nation after the civil war that devastated the country between 1977 and 1992. It seeks to understand how the nation is constituted in a country of ethnic diversities, where there is a population that often does not identify with the representation of a Mozambican identity proper, despite the efforts of the state governed by FRELIMO in outlining these men. The person of Mia Couto himself will also be analyzed historically, since his writing is intertwined with his political

${ }^{1}$ Mestrando em História pela Universidade Federal do Paraná.

Revista Vernáculo n. ${ }^{\circ} 41$ - primeiro semestre /2018

ISSN 2317-4021 
position. Thus, we will try to understand through this literary work the complex composition of the Mozambican nation.

Key Words: Mia Couto, Mozambique, Nation.

\section{Introdução}

Neste curto artigo será tratada de maneira breve de que forma a nação é retratada na literatura de Mia Couto. A literatura neste trabalho se apresenta como uma forma de o autor se expressar e demonstrar a sua visão de mundo. Dessa maneira é necessário entender o contexto em que vivia Mia Couto, que o influenciou a escrever Um rio chamado tempo, uma casa chamada terra. De maneira geral, Moçambique é composto por diversos grupos de diferentes etnias, que se estabeleceram na região a centenas de anos. A partir dessa variedade cultural, visualiza-se uma dificuldade em se pensar na unidade nacional, bem como no sentimento de nacionalidade unificada o que irá conflitar diretamente com o projeto de unificaçãoencabeçado pela FRELIMO (Frente de Libertação de Moçambique). Colonizada por Portugal, a luta para a independência foi armada, dirigida pela FRELIMO, fundada em 1962. Influenciada pelo contexto de guerra fria dos anos 70, a FRELIMO assumiu o caráter autodeclarado marxista-leninista que propôs políticas sociais baseadas na ideia de governo centralmente planificada e cujo corolário deveria a formação de um Homem Novo, socialista, que abandonaria a estrutura colonial racialista cimentada na sociedade pelas políticas da administração portuguesa, para então assumir um caráter nacional baseado no cientificismo e cujo sujeito histórico deveria ser o Homem Novo projetado. Esse "homem novo" Revista Vernáculo n. ${ }^{\circ} 41$ - primeiro semestre /2018 
deveria deixar de lado o tribalismo, a superstição e as tradições, pois deveria pautar a sua vida na educação e no trabalho, principais agentes de transformação segundo a FRELIMO. Um outro fator importante que influenciou na escrita do autor, foi o período de guerra civil pelo qual o país passou. Nesse conflito, foram protagonistas a FRELIMO e a RENAMO (Resistência Nacional Moçambicana), financiada por países como a África do Sul e a Rodésia do sul que viam no sistema marxistaleninista uma ameaça ao seu sistema vigente que era capitalista e de apartheid. A RENAMO possuía o apoio de parte de grupos tradicionais moçambicanos que não apoiaram a FRELIMO, visto que com o projeto modernizador, as lideranças tradicionais não eram legitimadas o que acentuou os conflitos e proporcionou maior força de apoio à RENAMO. A guerra ocorreu de forma muito violenta, chegando a todas as regiões do país. Seu final bélico ocorreu até 1992, quando foi assinado um Acordo de Paz em Roma, entretanto ainda é possível observar discordâncias e conflitos ideológicos nos dias atuais.

É importante pensar que o foco do artigo não é tratar do livro em si e de suas construções gramaticais, mas sim analisar de que maneira o autor pensa a escrita do livro e como isso traduz o seu pensamentos e posições na sociedade. Assim a literatura por não ser um registro oficial como um documento governamental, por exemplo, tem a capacidade de mostrar diferentes aspectos de uma sociedade que não são apresentados em discursos oficiais. Ou seja, a elasticidade e a licença poética da literatura nos permitem entender melhor setores da sociedade que

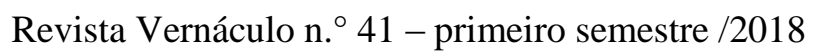

ISSN 2317-4021 
muitas vezes não são contemplados e que fogem aos olhos dos historiadores. Ao utilizar o texto literário como fonte, é importante articulá-lo pensando tanto as representações da prática, quanto as práticas da representação, como aponta Chartier ${ }^{2}$. Dessa maneira, para esse autor a obra literária deve ser vista para além das suas páginas escritas, ela deve compreender antes de mais nada as questões que envolvem a sua produção, o local do autor e a leitura do leitor. Ao analisar estas questões em conjunto com o texto, acaba por se fazer uma leitura histórica da literatura que busca a reconstrução de processos e de conjuntos nos quais os livros estão inseridos. Na obra há uma dimensão transitiva na qual há algo em representação que é encontrado também por meio de uma representação, ou seja, existe mais de um significado na representação tanto na história que o autor está de fato contando, quanto na representação do autor.

Dessa forma é necessário entender então o local de onde o autor escreve. António Emílio Leite Couto, conhecido por Mia Couto, nasceu na cidade de Beira, localizada na região central de Moçambique em 1955. É o autor moçambicanos mais traduzido e divulgado no estrangeiro, tendo suas obras publicadas em mais de vinte e cinco países. Mia Couto também é correspondente da Academia Brasileira de Letras. Recebeu diversos prêmios de literatura pelo mundo, entre eles o NomaAward em 2002 com o livro Terra Sonâmbula, que é considerado

${ }^{2}$ CHARTIER, Roger. Cultura Escrita, Literatura e História. Porto Alegre: Artmed, 2001

Revista Vernáculo n. ${ }^{\circ} 41$ - primeiro semestre /2018

ISSN 2317-4021 
um dos doze melhores livros do século XX de toda a África ${ }^{3}$; e também recebeu o Prêmio Camões em 2013. O moçambicano é filho do meio de um casal português que se estabeleceu em Moçambique. Cresceuem um Moçambique que ainda era considerado uma província ultramarina, ou seja, uma colônia na qual Portugal administrava em suas colônias uma política de assimilacionismo, onde os negros assimilados não eram considerados de fato cidadãos plenos portugueses, o que indica que a questão da discriminação racial era algo muito perceptível nessa sociedade. Dessa forma, o que se vê é que existia uma estratificação social entre negros e brancos, e Mia Couto, como um branco descendente direto de portugueses vivia e percebia essa diferenciação entre essas camadas da população.

Como aponta Braúna, Mia Couto escreve que quando criança seus pais eram muito progressistas, permitindo que ele convivesse com os negros, brincando na rua e conversando no cotidiano. Entretanto ele ponta que mesmo com essa liberdade, haviam restrições impostas no convívio devido ao racismo. Essa situação de viver no mundo colonial sendo privilegiado por ser branco e percebendo o racismo em volta desse contexto, fez com que Mia Couto se definisse como um homem de fronteira que vivia a "Europa em sua casa, e a África do outro lado da rua" ${ }^{4}$ questão essa importante para se entender a forma como o autor escreve, bem como o seu engajamento político.

${ }^{3}$ BRAÚNA, J.D. Nyumba-kaya:a delicada escrevência da nação moçambicana na obra de Mia Couto, Fortaleza, 2011.p. 73

${ }^{4}$ BRAÚNA, op.cit. p.34.

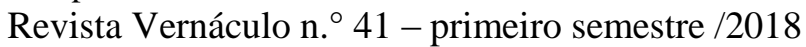

ISSN 2317-4021 
Influenciado pelo contexto de revolução e de engajamento político, Couto larga a faculdade de medicina para se dedicar às questões da luta de emancipação, Braúna aponta que Mia Couto e sua geração estavam empolgados com a ideia de se criar uma sociedade nova, sentimento esse que se modificará posteriormente e que será importante para entender a produção de Mia Couto pós $1983^{5}$.Mia Couto passa então a trabalhar como jornalista em frentes clandestinas até que se incorpora a FRELIMO no mesmo cargo em 1974, visto que os brancos não poderiam se inserir na luta armada ficando mais restritos ao pensamento teórico e divulgação dos ideais da FRELIMO. Com a independência o autor foi escolhido para ser diretor da Agência de Informação de Moçambique, onde permaneceu de 1976 até 1979, depois foi trabalhar na revista Tempo, de 1979 a 1981 e em seguida trabalho até 1985 no Jornal de Notícias ${ }^{6}$.O autor discorre sobre o período que trabalhou como jornalista:

Durante esse período eu consegui fazer um jornalismo engajado, a serviço da revolução, e isso eu fiz com grande dedicação. Hoje reconheço que havia muita coisa que não faria novamente, mas essa foi uma entrega de alma num período muito ético da história do nosso país, quando estávamos reconstruindo uma nação embriagados por uma causa. Depois houve um divórcio entre aquilo que era prática e o discurso, e pedi para sair do governo ${ }^{7}$.

${ }^{5}$ Ibidem. p.44.

${ }^{6}$ Ibidem.

${ }^{7}$ COUTO, Mia. Moçambique: 30 anos de independência, APUD Braúna,p.11.

Revista Vernáculo n. ${ }^{\circ} 41$ - primeiro semestre $/ 2018$

ISSN 2317-4021 
No final do trecho fica evidente que Mia Couto se descontentou com a FRELIMO, isso sedeve ao fato de o autor não concordar com os rumos políticos que o partido tomou após a independência e o projeto violento do Homem Novo, bem como a atitude dos integrantes como apresentado no trecho acima quando ao autor fala da distância entre teoria e prática. A trajetória de Mia Couto como um homem de fronteira é percebida na sua forma de escrita. Seu texto é carregado de elementos que combinam tanto a sua descendência portuguesa, quanto a sua experiência como Moçambicano. Assim, o autor busca abarcar em sua escrita os vários universos que constituem o país, enxergando como os sujeitos são múltiplos e as culturas dinâmicas, como aponta Campos ${ }^{8}$ que exemplifica na citação a seguir:

\begin{abstract}
O meu país tem países diversos dentro, profundamente dividido entre universos culturais e sociais variados. Sou moçambicano, filho de portugueses, vivi o sistema colonial, combati pela independência, vivi mudança radicais do socialismo ao capitalismo, da revolução à guerra civil. Nasci num tempo de charneira, entre um mundo que nascia e outro que morria. Entre uma pátria que nunca houve e outra que ainda está nascendo. Essa condição de um ser de fronteira marcou-me para sempre. As duas partes de mim exigiam um médium, um tradutor. A poesia veio em meu socorro para criar essa ponte entre dois mundos distantes ${ }^{9}$.
\end{abstract}

${ }^{8}$ CAMPOSJosilene.S. As representações da Guerra Civil e a Construção da Nação Moçambicana nos Romances de Mia Couto (1992-2000), Goiânia, 2009.p. 73.

${ }^{9}$ COUTO. E se Obama fosse africano e outra interinvenções. São Paulo, Companhia das Letras, 2011.pg 116

Revista Vernáculo n. ${ }^{\circ} 41$ - primeiro semestre /2018

ISSN 2317-4021 
Dessa maneira, a escrita do autor não se limita a criar apenas um mundo ilusório de narrativas que não possuem conexão com o seu presente ou com a História de Moçambique. O que se vê nas suas linhas são textos de contestação que, como aponta Campos, reinterpreta o passado, desvela a persistência dos efeitos da colonização na atualidade. É também possível perceber uma denúncia ao eurocentrismo imperialista bem como a denúncia dos estereótipos proveniente do tempo colonial e a manutenção de um sentimento de inferioridade, ou seja, uma narrativa que se compromete com o "entre lugar" em que o autor cresceu e que se formou Moçambique ${ }^{10}$.

Quanto às maneiras e modelos linguísticos, observa-se que o autor utiliza de neologismos, criando palavras que demonstram como ele encara o fato de não existirem palavras prontas que consigam passar para o leitor esse hibridismo no qual sua escrita está inserida, ou seja, é na recombinação lexical que se formam uma das marcas do autor. Assim, o escritor procura descrever sentimentos que não são traduzíveis na língua oficial do colonizador. Exemplos disso são encontrados em diversos de seus textos. Em 1994 (2012 aqui no Brasil) o autor lança o livro "Estórias Abensonhadas"11 onde observa-se a junção das palavras abençoada e sonhada para a criação do título do livro. No conto "Jorjão vai embalando lembranças" do mesmo livro encontra-se a palavra pedinchorar, uma mistura de pedinte com chorar, para se referir a uma criança de rua. Um outro exemplo neste mesmo conto é a

${ }^{10}$ CAMPOS, op.cit. p 79.

${ }^{11}$ COUTO, Mia. Estórias abensonhadas. São Paulo. Cia. Das Letras, 2012.

Revista Vernáculo n. ${ }^{\circ} 41$ - primeiro semestre /2018

ISSN 2317-4021 
palavraacrediteísta, que segue a mesma linha de pensamento ao que condiz aos neologismos. Além de palavras, o autor também faz trocadilhos com expressões como ditos populares, o que só é possível entender devido ao fato de o escritor escrever em português. Mia Couto aponta: “Eu já bebia na poesia um gosto pela desobediência da regra [...] eu experimentei o gosto pelo namoro entre língua e pensamento, o gosto do poder divino da palavra"12. Assim, observamos expressões tais como: olho por olho, dente prudente, encontrado no conto "Os infelizes cálculos da felicidade" e a expressão "Para meio entendedor, duas palavras não bastam", encontrado no conto "Pranto de coqueiro", ambos do livro EstoriasAbensonhadas. Com isso, observa-se que a reinvenção da língua portuguesa operada pelo autor é uma forma de demonstrar uma reflexão histórica, político social e ideológica na qual o autor está inserido ${ }^{13}$.

Muito desse neologismo usando por Mia Couto deve-se ao fato de o autor prezar muito sobre a questão da oralidade na escrita. Em uma intervenção que o autor fez em Minas Gerais em 2007, Mia Couto discorre sobre a importância da obra de Guimarães Rosa para sua escrita. Nesse sentido, ele aponta que tanto no Brasil, quanto em Moçambique e em Angola, se presava muito pela estética da escrita realista. Mas, para ele (e nisso ele inclui Guimarães Rosa como um protagonista desse rompimento no qual se inspirou), existe uma lógica diferente que escapava das questões políticas e realistas. Assim, ele

${ }^{12}$ COUTO,Mia. E se Obama... op. cit. 2011,p. 109

${ }^{13}$ CAMPOS,op.cit. p.75.

Revista Vernáculo n. ${ }^{\circ} 41$ - primeiro semestre /2018

ISSN 2317-4021 
aponta que era preciso sair da razão para se poder olhar dentro da alma dos brasileiros. Como aponta:

Como se para tocar a realidade fosse necessária uma certa alucinação, uma certa loucura capaz de resgatar o invisível. A escrita não é um veículo para se chegar a uma essência, a uma verdade. A escrita é a viagem interminável. A escrita é a descoberta de outras dimensões, o desvendar de mistérios que estão para além das aparências. [...] Através de uma linguagem reinventada com a participação dos componentes culturais africanos também nós em Angola e Moçambique procurávamos uma arte em que os excluídos pudessem participar da invenção da sua História ${ }^{14}$.

Nessa necessidade de inserir os excluídos na construção de sua própria História, é que Mia Couto ressalta a importância de se usar a oralidade em seus escritos. Assim, ele afirma que ao usar a oralidade, o autor foge da hegemônica lógica racionalista como o único modo de se apropriar do real ${ }^{15}$. Com isso, ele se abre para múltiplas realidades, aceitando as diversas possibilidades que se constituem uma escrita literária. A utilização dos neologismos e de expressões locais se traduz como uma desobediência ao modo hegemônico, trazendo para a escrita termos Bantu, por exemplo, Mia Couto traz uma feição moçambicana para a escrita, além do português que é em suma a língua do colonizador. Assim, Campos aponta que na sua busca por afirmação, reconhecimento e autoconhecimento, o autor encontra nas variações

${ }^{14}$ COUTO, Mia. E se Obama... op.cit. 2011, p. 114

${ }^{15}$ Ibidem p. 116.

Revista Vernáculo n. ${ }^{\circ} 41$ - primeiro semestre /2018

ISSN 2317-4021 
linguísticas uma aliada para se inserir neste campo. A autora ainda explana que Mia Couto não nega a língua do colonizador, mas sim mostra como ela é suscetível às mudanças e como aliada a elementos africanos, latinos e orientais acabou por se tonar uma língua moçambicana ${ }^{16}$. A literatura do autor se encontra num ambiente de busca de identidade e autenticidade, característico de literaturas póscoloniais ${ }^{17}$, pois o que se observa é que há um esforço de se reescrever a História do país, e também de pensar numa escrita da nação.

\section{A nação de Mia Couto}

Os diversos sujeitos que constituem a nação moçambicana podem ser encontrados nos personagens que compõem a narrativa da obra de Mia Couto aqui estudadaUm rio chamado tempo, uma casa chamada terra, publicada originalmente pela editora caminho em 2002 e pela editora Companhia das Letras aqui no Brasil em 2003. Nessa obra é possível observar para além de outros aspectos a situação que o país se encontra após os longos anos de guerra civil. Assim, o que se depara nesse cenário é um Estado que possui debilidadesno seu relacionamento com a população. Já nas primeiras páginas do romance se observa a referência em relação a nação, isso ocorre devido ao fato

\footnotetext{
${ }^{16}$ CAMPOS, J. op. cit. p. 77.
}

${ }^{17}$ Aqui o termo pós-coloniais se refere ao período temporal, após as independências africanas. Entretanto existe também a linha teórica de mesmo nome que também é relevante, entretanto nesse artigo não será mais profundamente discutida. Para mais Hall, Stuart. "Quando foi o pós-colonial? Pensando no limite." Da Diáspora. Belo Horizonte, Ed. UFMG (2003).

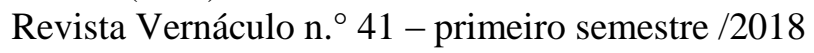


de que o nome da casa onde se passa a maior parte do enredo chama-se "Nyumba-Kaya" (doravante sem aspas) e significa casa em seus dois termos, o primeiro (Nyumba) sendo reconhecido nas línguas faladas no norte do país e o segundo (Kaya) nos idiomas do sul. A partir desse aspecto, observa-se que esta casa sendo nomeada pelo autor com esses dois significados pode ser entendido como o próprio país Moçambique, dividido a grosso modo em duas partes e populações diferentes, tanto por suas etnias estabelecidas desde a sua formação, quanto pelas políticas coloniais aplicadas de diferentes formas nas regiões.Uma questão a ser levada em consideração é a de que o autor divide o país em dois, entretanto, usualmente, o país é divido em três, sendo o norte o centro e o sul. Essa característica é importante de ser observada, pois pode demonstrar de que maneira o próprio autor enxerga o país. Nas palavras de Mia Couto ele apresenta o dualismo entre norte e sul da seguinte maneira: "São duas nações, mais longínquas que planetas. Somos um povo sim, mas de duas gentes, duas almas" "18. É nesta casa que se passa a maior parte do enredo, nela, os Marianos (nome aportuguesado de "Malinanes", família a qual pertencem as personagens) irão vivenciar a cerimônia fúnebre do avô morto-vivo ${ }^{19}$, que está repleta de mistérios e conflitos entre as gerações. Uma outra questão entre os personagens é a relação que estes possuem com o local

${ }^{18}$ COUTO, Mia. Um rio chamado tempo, uma terra chamada casa. São Paulo: Cia. Das Letras, 2003, p.18.

${ }^{19}$ Esta "não morte" é u mistério até mesmo dentro do enredo, não há um consenso se Dito Mariano está morto. Ao se corresponder com o neto através de cartas, esta incerteza aumenta, e só é desvendada no final do livro.

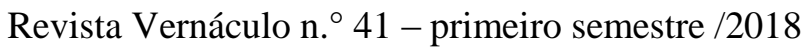

ISSN 2317-4021 
onde vivem Luar-do-chão, um local que segundo os personagens se modificou após a chegada de indivíduos suspeitos que já tinham feito parte da comunidade, mas não pertenciam mais àquele lugar. Dessa maneira, eles são vistos como gananciosos e são responsáveis por Luardo-Chão não se configurar como antigamente. Em cada personagem é possível perceber os diferentes sujeitos que compõem na visão do autor a nação moçambicana como já mencionado, numa analogia de certa forma idealizada que veremos a seguir mais detalhadamente.

O personagem principal e também narrador do livro é Marianinho, jovem rapaz que retorna à Luar-do-Chão, para o funeral do seu avô ${ }^{20}$. Durante alguns dias, aproximadamente onze, o rapaz é responsável por conduzir o funeral de seu avô, que não pode ser enterrado devido a pendências e a não confirmação de sua morte. Desse modo, no decorrer do livro Marianinho recebe cartas que chegam as suas mãos com instruções para que o jovem resolva alguns conflitos para que o avô possa ser definitivamente enterrado. Ao regressar a este lugar, e se estabelecer na Nyumba-Kaya, Marianinho percebe como ele, enquanto pessoa mudou, e não se identifica mais com as crenças e rituais ali perpetuados.

Nos quartos, nos corredores, nas traseiras se aglomeram rostos que, na maior parte, desconheço. Há anos que não visito a Ilha. Vejo que se interrogam: eu, quem sou? Desconhecem-me. Mais

${ }^{20}$ No final da trama descobre-se que na verdade Marianinho era filho de Dito Mariano, e não neto como se pensava no decorrer do livro.

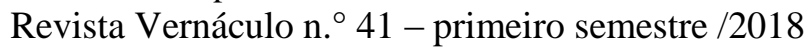

ISSN 2317-4021 
do que isso, irreconhecem-me. Pois eu, na circunstância, sou um aparente parente. Só o luto nos faz da mesma família ${ }^{21}$.

Grosso modo, o que se observa é que Marianinho pode ser percebido como o indivíduo que nasce em Moçambique após o período colonialista, e cresce com a ideia do projeto do Homem Novo da FRELIMO, que é cientificizado e pautado no modelo de homem moderno racional pretendido para a nova nação. Assim ele não se sente completamente à vontade com as questões referentes ao funeral do seu avô, pois não existe ali uma identificação imediata com a tradição, questão essa que se modifica ao longo do livro e que será de suma importância ao final para poder se entender como Mia Couto vê a questão da importância da tradição para a resolução dos problemas sociais em Moçambique.

Ao retornar para seu lugar de origem, Marianinho perpassa todas as suas relações pessoais com os seus familiares. A primeira a ser tratada aqui será a relação com o seu pai Fulano Malta. Ex guerrilheiro da luta armada, Fulano é retratado como uma pessoa desiludida com os rumos que o país tomou. Este personagem é visto como profundo e pouco comunicativo sobre a questão da guerra, o autor discorre:

[...] nem o casamento lhe foi suficiente. Pois seu viver se foi amargando e ele, mal escutou que havia

${ }^{21}$ COUTO, Um rio chamado... op. cit. 2003, p. 30.

Revista Vernáculo n. ${ }^{\circ} 41$ - primeiro semestre /2018

ISSN 2317-4021 
guerrilhas lutando por acabar com o regime colonial, se lançou rio afora para se juntar aos independistas ${ }^{22}$.

Mais além, no livro ocorre um diálogo entre Fulano e sua esposa no dia em que se oficializa a independência no país, no qual o exguerrilheiro comenta: “...aqueles que, naquela tarde, desfilavam bem na frente, esses nunca se tinham sacrificado na luta. E nunca mais Fulano falou de políticas..."23. Aqui se percebe uma figura que se empenhou na guerra de libertação, entretanto, no final do conflito e a despeito das políticas da FRELIMO acabou por se desiludir, pensando até mesmo numa continuidade da FRELIMO e do tempo colonial de Portugal $^{24}$. Essa característica fica mais evidente no seguinte trecho de uma conversa entre Fulano Malta e seu pai, Dito Mariano (ainda quando estava vivo, num momento de lembrança do primeiro): “Que esses que diziam querer mudar o mundo pretendiam apenas usar da nossa ingenuidade para se tornarem novos patrões. A injustiça apenas mudava de turno "25

Abstinêncio é o mais velho dos filhos de Dito Mariano. Ele possui a incumbência de anunciar a morte de seu pais para os demais familiares, o que fez ao comunicar a morte a Marianinho. Abstinêncio é

${ }^{22}$ COUTO, Um rio chamado... op.cit. 2003, p.72.

${ }^{23}$ Ibidem p.73.

${ }^{24}$ Essa discussão é extensa e infelizmente não cabe nesse artigo, para mais é interessante ler : CAHEN, Michel. "Em Moçambique só há partido de direita" Entrevista In. PLURAL, Revista do Programa de Pós-Graduação em Sociologia da USP, São Paulo, v.20.1,2013, pp.155 - 174 e MACAGNO, Lorenzo. "Fragmentos de uma imaginação nacional”. In; RBCS, 2009, vol.24, no.70, p.17-35

${ }^{25}$ Ibidem.p.222.

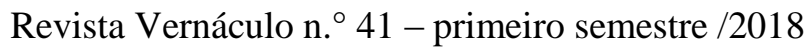

ISSN 2317-4021 
uma figura reservada, do tipo que como Marianinho explica, não saia de casa por razão alguma o que já fica claro no seu nome "Abstinêncio" como se ele já se tivesse abstido de viver a sua vida. No livro se explica o desânimo do personagem por conta de um amor não correspondido. Sempre tecendo críticas ao irmão mais novo Ultímio, Abstinêncio não se conforma com as escolhas do irmão. Tio Ultímio, é um assimilado ${ }^{26}$ e que possui funções políticas dentro do país e quase não se encontrava mais em Luar-do-Chão. Tio Ultímio é visto com desconfiança pelos demais personagens, pois no pensamento coletivo ele acabou por se distanciar das tradições e da população de Luar-do-Chãoao assumir a cultura portuguesa. Uma questão que corrobora com este pensamento é o fato de que Ultímio pretende vender a NyumbaKaya, pois vê em Luar-do-chãoum grande potencial econômico. Sobre tio Ultímio, Marianinho explica o sentimento que tio Abstinêncio possui em relação ao irmão:

Não era tanto a pobreza que o derrubava. Mais grave era a riqueza geminada sabe-se lá em que obscuros ninhos. E a indiferença dos poderosos para com a miséria de seus irmãos. Esse é o ódio que ele fermentava contra Ultímio. Meu tio mais novo visitava a Ilha, cheio de goma e colarinho. Ele e seus luxos, arrotando ares. Entrava e saía sem licença, todo inchado, feito bicho graúdo.- É um desses que pensam que são senhores só porque são mandados por novos patrões $^{27}$.

${ }^{26}$ Assimilados são os moçambicanos que se submeteram ao projeto colonizador de transformar os indivíduos moçambicanos em novos portugueses.

${ }^{27}$ COUTO, Um rio chamado... op.cit. 2003 p.118.

Revista Vernáculo n. ${ }^{\circ} 41$ - primeiro semestre $/ 2018$

ISSN 2317-4021 
É possível perceber também a relação de Marianinho com sua avó, Dona Dulcineusa que, junto de seu avô deposita em Marianinhoa esperança da mudança num país devastado pela guerra e corrupção. Dulcineusa é uma mulher de origem e de modos simples, casada com Dito Mariano desde jovem, viveu a vida em função de cuidar da família e do marido, que segundo ela dava muito trabalho por ser mulherengo. Em suas falas, percebe-se uma serenidade proveniente dos anos de experiência e da sua religiosidade. Quando Marianinho chega emLuardo-Chão, a avó o incumbe de cuidar da cerimônia fúnebre do avô, mesmo que este lugar seja reservado normalmente para o filho homem mais velho do falecido. Em meio a relutância dos outros filhos, Dona Dulcineusa aponta:

Eu não confio em mais nenhum. Só em você, meu neto, só em você eu deito fianças [...]. É aqui onde escondo as chaves todas da NyumbaKaya. Você vai guardar estas chaves, Mariano. [...] tome e guarde bem escondido. Guarde esta casa, meu neto $!^{28}$.

O que Dulcineusa demonstra é uma falta de confiança nos outros integrantes da família, mas também cabe aqui pensar que ela foi orientada por Dito Mariano a agir dessa forma. Admirança é outra personagem que possui importância no livro e seu nome já revela a sua boa aparência e formas. Meia irmã de Dulcineusa e muitos anos mais

${ }^{28}$ Ibidem. p. 33.

Revista Vernáculo n. ${ }^{\circ} 41$ - primeiro semestre /2018

ISSN 2317-4021 
nova, Admirança nunca se casou e sempre esteve perto da irmã. Marianinho possui um sentimento diferente em relação à tia e sua história é repleta de mistérios. Isso ocorre pelo fato de que no final do livro o que se revela é que Admirança na verdade é a mãe de Marianinho, que é fruto do adultério com Dito Mariano, esposo de sua irmã. Para não levantar suspeitas, Admirança carrega consigo o estigma de dizer que é estéril e o filho foi dado para criar para Mariavilhosa, esposa de Fulano que de fato não poderia ter filhos. Mariavilhosa é a "falsa mãe" de Marianinho. Quando mais nova, fora violentada pelo patrão português Frederico Lopes e ao fazer um aborto adoeceu gravemente, e necessitou de cuidados médicos que só existiam em Luar -do -Chão.Ao fazer estas viagens, travestida de homem pois apenas os trabalhadores poderiam usar o barco que era proibido para os demais negros, Mariavilhosaconhece Fulano Malta, por quem se apaixona e se casa, entretanto devido ao aborto Mariavilhosa encontra dificuldades em engravidar

$\mathrm{Na}$ altura do funeral do avô, Mariavilhosa já é falecida, e como aponta Saraiva $^{29}$ o seu espectro ronda a narrativa como uma outra morte indefinida visto que ela morreu afogada, mas apontam como um suicídio da qual Marianinho precisa resolver para apaziguar os conflitos da família, mistério esse que será contado pelo padre Nunes. Ainda sobre essa questão dos filhos e Mariavilhosa, é necessário fazer algumas

\footnotetext{
${ }^{29}$ Saraiva, Sueli da Silva. A experiência do tempo em dois romances africanos: Um rio chamado tempo, uma casa chamada terra e Mãe, materno mar. Diss. Universidade de São Paulo, 2008.
}

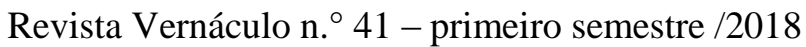


considerações. Após ter aceitado a propostas de Dito Mariano e depois de ter criado Marianinho, Mariavilhosa engravida de Fulano Malta, e o interessante é que a gestação dura o tempo do final da guerra de Independência, onde Fulano havia lutado e o nascimento é previsto para o dia em que a bandeira iria se erguer. Entretanto, o filho do casal nasce morto, o que vai causar maior desgosto nos pais e culminará na morte de Mariavilhosa e na constante amargura de Fulano Malta. Podemos perceber aqui, metaforicamente, que Fulano Malta via nesse filho um futuro, assim como veria um futuro melhor para o seu país com a independência. Entretanto o que acontece é que o filho já nasce morto, e podemos pensar que é assim que Fulano enxerga essa nova fase do país, que mesmo com novos comandantes, não vai inserir e mudar de fato diversas questões de Moçambique. Aí vemos a forma como Mia Couto enxerga esse período, e que confere ao Moçambique independente a característica onde a ideia revolucionária permanece nas mãos de uma elite e os projetos entre colonialismo e FRELIMO são semelhantes.

O padre Nunes que é confidente de Dulcineusa e está prestes a se afastar de Luar-do-Chão pois sabe muitos segredos da Ilha dos quais não consegue conviver, principalmente com as confissões de Frederico Lopes, que comete atrocidades contra a população da Ilha e ao se confessar se sente impune. Esse movimento de impunidade faz com que o Padre peça afastamento da ilha. Frederico Lopes é um português que vivia na ilha e se torna padrinho de Marianinho e benfeitor do mesmo enquanto este se estabelece na cidade visto que os Marianos não sabiam

Revista Vernáculo n. ${ }^{\circ} 41$ - primeiro semestre /2018

ISSN 2317-4021 
do que ele havia feito à Mariavilhosa (ele apenas confessou ao padre, que depois contou para Marianinho). Sua esposa portuguesa Conceição é a causa da desilusão amorosa de Abstinêncio. Conceição detesta o próprio marido pelo o que ele fez à Mariavilhosa, e nutre amores para com Abstinêncio. Dito Mariano, o avô de Marianinho é um dos personagens chave para entender o livro, visto que toda a narrativa se passa no período de seu funeral. Como já dito anteriormente, Dito Mariano possuía fama de malandro, e assim continua após a sua morte. O que se pode compreender desse personagem é que suas características estão de acordo com o período em que viveu. Como conheceu Moçambique durante o período colonial e o período de libertação, se observa nele um desânimo com os rumos do país. Essa característica é muito observada em todos os personagens que passaram este período, até mesmo em Ultímio. Todos percebem que existe algo diferente em Luar-do-Chãoque pode acabar prejudicando todo o local, e isto vem principalmente do distanciamento das tradições.

O coveiro Curozero é responsável por cuidar do cemitério da ilha. Conhecedor dos mistérios de morte e vida, Curozero auxilia Marianinho com o enterro de seu avô. Esse personagem é ligado a dois outros personagens chave da História. O primeiro é Juca Sabão seu pai, que era amigo de Dito Mariano, entretanto foi assassinando a sangue frio por causas que serão abordas posteriormente. Curozero é também irmão de Nyembeti, moça simples que vive em Luar-do-Chãoe não fala a língua portuguesa e que desperta a curiosidade de Marianinho. Ao

Revista Vernáculo n. ${ }^{\circ} 41$ - primeiro semestre /2018

ISSN 2317-4021 
nascer, Nyembeti fora picada por uma cobra venenosa, que ao invés de matá-la a tornou mais forte. Quando criança, a menina já havia se encontrado com Marianinho, para brincarem como se recorda o menino. Com a dificuldade da fala Nyembeti utiliza-se apenas da expressão: “Mali (dinheiro)! Nikumbelamali!(estou a pedir)" uma expressão para pedir dinheiro, o que como aponta Saraiva é uma forma de expressar a miséria social na qual se passa Moçambique. Cobiçada também pelo tio Ultímio, Nyembeti recusa qualquer ajuda do mesmo, deixando se levar e espiar apenas por Marianinho.

Nas primeiras páginas do livro, Marianinho se encontra com seu tio Abstinêncio, que lhe dá a notícia do funeral do seu avô, e por isso ele terá que retornar a Luar-do-Chão, sua ilha de nascença da qual saiu para estudar. No funeral irão se encontrar todas a família na NyumaKaya, local que abrigara os de dentro e os de fora da Ilha. Mia Couto aponta apenas um dualismo, como se existisse a ilha e a cidade no país, separados apenas por um rio, mas em outras questões entre os dois lados se reside um infinito, segundo o autor. Dessa forma podemos perceber que Mia Couto observa uma grande distância entre os dois opostos do país: as áreas rurais e as cidades. Desde a colonização essas áreas foram tratadas diferentemente. Durando o período de guerra, o tratamento foi o mesmo do período colonial o que acentua a diferença entre ambos lugares.No livro, o espaço da Ilha é reservado como o lugar onde a tradição reside, entretanto este está em constante ameaça de modernização, de se venderem àqueles que não pertencem aquela terra, 
e é nesse sentido que a presença de Marianinho vai influenciar. Como apontamos anteriormente, muitos personagens possuem este sentimento de certa forma de desânimo em relação ao que pode ocorrer com Luardo- Chão, eles possuem medo de que a ilha seja vendida e se torne algo que eles próprios não reconhecem e não se identificam mais. Silvia Saraiva aponta que "a preocupação do avô é restabelecer os laços familiares, o respeito pelo patrimônio cultura, e mesmo a preservação física dessa comunidade, desmantelada pela ganância dos novos mandantes" ${ }^{30}$. A outra preocupação que se passa durante o livro e é o que impede que o avô seja enterrado são os próprios segredos do avô, que no final do livro se descobre sobre a mentira da paternidade de Marianinho bem como a venda da arma que ele suspeita que matou seu amigo Juca Sabão. Esses dois aspectos são o que norteiam o livro e acabam por decidir sobre o funeral e guiar todas as ações de Marianinho. Assim, como aponta Saraiva, Marianinho deverá conhecer a si mesmo, conhecer os segredos da ilha e de sua gente e trazer para a ilha a junção desse entendimento com os processos de mudanças que a ilha vêm sofrendo desde a colonização, passando pela luta de independência e o estabelecimento de novas bases de poder ${ }^{31}$. Marianinho terá que restabelecer estes elos para que a paz se restabeleça tanto em Luar- do- Chãoquanto na sua própria família (que aqui podemos ver até mesmo como a própria Ilha).

${ }^{30}$ SARAIVA,op.cit.p.22.

${ }^{31}$ Ibidem.

Revista Vernáculo n. ${ }^{\circ} 41$ - primeiro semestre /2018

ISSN 2317-4021 
Este abalo e o desejo de estabilização se deve a questão que a morte do velho Mariano pode significar também o afastamento e o desmantelamento da família. Assim, a casa e Dito Mariano são o elo que mantém a família unida. Como aponta a Saraiva: "A casa e o patriarca são como um só corpo: o patrimônio cultural que se está perdendo, um tempo que se está esgotando e que precisa voltar a ater contato com o presente para sobreviver no futuro ${ }^{32}$. E é Marianinho que representa tanto este presente, quanto o futuro que irá ser responsável por fazer esta conexão.

Dito Mariano irá se comunicar com Marianinho através primeiramente de bilhetes, que depois se tornarão cartas mais extensas. As cartas são escritas como uma forma de psicografia, no caso o avô estaria incorporando no neto, para que ele as redigisse, questão que Marianinho só percebe depois de algumas cartas, antes disso ele desconfia ser alguns de seus tios que poderia estar escrevendo. Assim, das cartas é possível tirar duas questões importantes que Mia Couto vê na relação entre o avô e o neto. A primeira é a questão da importância da ancestralidade onde os mortos permanecem na sociedade ainda ditando muitas vezes os acontecimentos e sendo na crença responsáveis por regular a ordem social, tais como a guerra, fome, seca chuva, casamento, infertilidade, azar e etc. Aportado nessa questão, Marianinho e Dito mariano possuem a relação deXará. Essa relação acontece quando um membro mais velho da família possui o seu nome

${ }^{32}$ SARAIVA, op.cit.p. 25

Revista Vernáculo n. ${ }^{\circ} 41$ - primeiro semestre /2018

ISSN 2317-4021 
colocado em um membro mais novo. Essa questão abre espaço para que o mais velho, quando morto permaneça no mais novo. Essa relação é muito forte e não é apenas uma homenagem ao mais velho, mais estabelece relações mais profundas de ancestralidade. Essa questão pode explicar o porquê de ser Marianinho o correspondente de Mariano, através das cartas. Isso fica mais claro no diálogo entre Marianinho e Abstinêncio quando viajavam para Luar-do-Chão:

-Agora que estamos a chegar, você prometa ter cuidado

- Cuidado? Porquê, Tio?

- Não esqueça: você recebeu o nome do velho Mariano. Não esqueça.

O Tio se minguou no esclarecimento. Já não era ele que falava. Uma voz infinita se esfumava em meus ouvidos: não apenas eu continuava a vida do falecido. Eu era a vida dele ${ }^{33}$.

Decorrente disso, evidencia-se a questão de Marianinho se permitir entrar em contato com o avô, com a casa e com a tradição para que seja completado as instruções do avô de apaziguar e unir a família. Esse ponto do apaziguamento fica também visível no trecho a seguir, da segunda carta que o avô mandou:

Como se diz aqui: feridas da boca se curam com a própria saliva. Esse é o serviço que vamos cumprir aqui, você e eu, de um e outro lado das palavras. Eu dou as vozes, você dá a escritura. Para salvarmos Luar-do-Chão, o lugar onde ainda vamos nascendo. E

${ }^{33}$ COUTO, Um rio chamado...op.cit.p.22

Revista Vernáculo n. ${ }^{\circ} 41$ - primeiro semestre /2018

ISSN 2317-4021 
salvarmos nossa família, que é o lugar onde somos eternos $^{34,}$

A questão do apaziguamento e da função de Marianinho é de suma importância para se pensar este trabalho, pois é a partir dessas relações e desse pensamento que veremos como Mia Couto pensa a configuração da nação. Uma outra questão que nos leva a pensar a relação entre os dois personagens é a do tempo. Como aponta Sueli Saraiva, as cartas têm o poder de estabelecer uma comunicação entre dois tempos diferentes. Mesmo o avô e o neto estando no mesmo local físico, habitando a mesma casa eles estão distanciados no espaço. A autora propõe que o avô semimorto está num espaço de transição, indo do presente para o passado, já o seu neto-filho que está vivo no presente e em transição para o futuro. Ou seja, estas cartas, que são um aspecto moderno, vinculam personagens que estão juntos no espaço e separados no tempo, o primeiro no tempo tradicional, passado do avô e o tempo presente e moderno do neto ${ }^{35}$.Assim, se observa que Mia Couto traz para a sua narrativa a questão de um tempo espiralar, muito presente na cosmografia africana. Baseada em Ricouer ${ }^{36}$, Saraiva aponta que na proposta espiralar, um movimento passa muitas vezes pelo mesmo ponto, mas numa altitude diferente, assim a cosmovisão entrelaça no mesmo circuito de significância, o tempo, a ancestralidade e a morte ${ }^{37}$. A autora aponta que seria possível observar nas obras e incluindo aqui a

${ }^{34}$ COUTO, Um rio chamado...op.cit.p.65.

${ }^{35}$ SARAIVA, op.cit.p.41.

${ }^{36}$ RICOEUR,P. Tempo e narrativa, Tomo 1. Campinas: papiros, 1994.

${ }^{37}$ Saraiva, op. cit. p.93.

Revista Vernáculo n. ${ }^{\circ} 41$ - primeiro semestre /2018 
obra de Mia Couto, que ao fazer esse movimento e considerar a cosmografia, se observa um processo de criação de suplementos que muitas vezes acabam por cobrir faltas e rupturas das culturas e dos sujeitos. Ou seja, quando Mia Couto traz a relação do filho com o avô, nesses dois tempos diferentes, mas que de certa forma se encontram, ele explana que é nessa relação de dois tempos, de tradição e modernidade que se encontrara a resolução dos conflitos de Moçambique, ou até mesmo a própria resolução da nação. As nove cartas enviadas por Dito Mariano conduzem a narrativa do livro e inseremMariano nesses dois tempos diferentes e o incube de salvar Luar-do-Chão, pois o lugar fora corrompido quando os dali se encheram de vaidades e corrupção, características que não eram intrínsecas a população dali, mas que se fortaleceu quando os deste lugar começaram a se corromper ${ }^{38}$, essa questão fica mais clara no trecho a seguir:

Essa terra começou a morrer no momento em que começamos a querer ser outros, se outras existências, se outro lugar. Luar-do-chão morreu quando os que a governam deixaram de a amar. Mas a terra não morre, nem o rio se suspende ${ }^{39}$.

O avô só consegue confiar em Marianinho, pois segundo ele os outros filhos não terão a capacidade de poder entender esse processo, pois como já são de Luar-do-Chão, e possuem suas próprias desilusões

${ }^{38}$ COUTO, Um rio chamado, op.cit. p. 195.

${ }^{39}$ Ibidem.

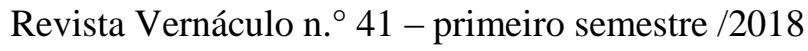

ISSN 2317-4021 
com o local e com as suas próprias vidas. Dessa maneira, querem que todo o processo do funeral do avô seja abreviado, entretanto o avô aponta que é necessário mais tempo, para que Mariano se aprofunde nas questões da tradição e complete a sua missão de apaziguar o local. Esse ponto fica mais evidente na seguinte carta que o avô direciona ao neto:

Mariano, esta é sua urgente tarefa: não deixe que completem o enterro. Se terminar a cerimonia você não receberá as revelações. Sem essas revelações você não cumprirá a missão de apaziguar espíritos com anjos, Deus com os deuses: Estas cartas são o modo de lhe ensinar o que você deve saber. Neste caso, não posso usar métodos da tradição: você já está longe dos Malilanes e seus xicuembos(espírito antepassado). A escrita é a ponte entre os nossos e os seus espíritos. Uma primeira ponte entre os Malilanes e os $\operatorname{Marianos}^{40}$.

Aqui observamos claramente a questão do apaziguamento e da necessidade de ser alguém que vem de fora e a necessidade de se fazer a ponte entre os Malinanes (passado) e os Marianos(presente/futuro) e também a questão da necessidade de se trazer toda a família para a Nyumba-Kaya. O avô precisa que toda a família seja reunida, até mesmo aqueles que já foram desprezadas pela mesma. Ou seja, Mia Couto enxerga que a nação só será recomposta a partir do momento em que todos os personagens que compõem Moçambique possam habitar o seu mesmo local em paz, quando a Nyumba-Kaya reestabelecer a sua relação com seus próprios habitantes.

${ }^{40}$ Ibidem. p. 126.

Revista Vernáculo n. ${ }^{\circ} 41$ - primeiro semestre /2018

ISSN 2317-4021 
Voltando para a ordem em que Mia Couto narra o livro, a avó Dulcineusa também protagoniza um momento em que se demonstra que os que governam estão corrompidos e ainda carregam heranças coloniais. Junto de Marianinho, Dulcineusa passa ao lado do administrador da ilha, quando para e faz como quem vai ajoelhar, quando o administrador aponta: “-Dona Dulcineusa, eu já disse para não fazer isso!" De modo que a senhora responde: “- Sim, senhor administrador. Por favor, não me bata, eu não tenho idade para palmatória! $!^{41}$ Assim, o narrador continua apontando:

O administrador sacode a cabeça. Ele não acredita que se trate de demência. Pensa que se trate de chacota com intenção política bem determinada: Dulcineusa faz de conta que o confunde com o administrador colonial. Apressadamente o governante atravessa a rua, antes que se juntem curiosos ${ }^{42}$.

Assim, nessa passagem Mia Couto reitera o seu pensamento, que já havia apresentado antes com Fulano Malta, de que a população não vê uma verdadeira mudança entre os dois períodos colonial/FRELIMO e a necessidade de se modificar essa situação ao aliar o tradicional e o moderno.

Muito do pensamento de que a ilha deve ser salva, vem dos momentos que o velho Dito Mariano passou antes de ficar não-morto. Dessa maneira, em uma das suas últimas cartas Mariano conta de que

${ }^{41}$ Ibidem.p. 26

${ }^{42}$ Ibidem.

Revista Vernáculo n. ${ }^{\circ} 41$ - primeiro semestre /2018

ISSN 2317-4021 
forma seu amigo Juca Sabão fora morto, pois segundo o Dito MarianoLuar-do-Chãocomeçou a morrer quando Sabão fora assassinado. Isso se deveu ao fato de que o sobrinho de Juca Sabão trouxe para a Ilha uns sacos que haviam uns pós, dos quais nem Mariano, nem Juca Sabão sabiam a função. A única coisa que sabiam é que o sobrinho disse que aqueles pós trariam riqueza para a ilha. Os sobrinhos de Juca Sabão já possuíam fama de bandidos e "mausfeitores"43. A partir disso, já havia uma desconfiança sobre a real utilidade daqueles pós. Assim, Juca e Mariano pensam que como o sobrinho disse que aqueles pós trariam riqueza para a terra, pensaram se tratar de adubo, e dessa forma deitaram o conteúdo na areia para "dar sustento ao chão". Após esse episódio, o sobrinho de Juca volta para a ilha e pelo ocorrido mata o próprio tio. Pensando assim, Mariano passou a ter a certeza que Marianinho deveria salvar Luar-do-Chão,pois "faltava-nos um que viesse de fora mas fosse de dentro. Pensava isto enquanto sentia como na nossa Ilha se misturavam o respirar da vida e o sopro da morte" 44 .

Dessa maneira, vemos mais uma vez a desconfiança dos que moram na capital, assim como ocorre com o tio Ultímio. Ou seja, ao relacionar a morte de Sabão com o fechamento da terra, Dito Mariano reforça o pensamento de que a terra começou a morrer no momento em

\footnotetext{
${ }^{43}$ Aqui Mia Couto se utiliza de sua característica principal, juntar mais de uma palavra pra dar-lhe sentido.

${ }^{44}$ Ibidem.p.173.
}

Revista Vernáculo n. ${ }^{\circ} 41$ - primeiro semestre /2018

ISSN 2317-4021 
que os próprios habitantes de Luar-do-Chãopassaram a querer ser outros, a não se identificar mais com a sua terra e a sua tradição.

Depois dessa revelação, o livro começa a se encaminhar para o seu final. Dessa maneira, Marianinho começa a perceber que a sua presença ali começa a realmente apaziguar as relações entre seus familiares. Numa certa ocasião, após sair do bar Marianinho é detido por policias, que o prendem e fazem perguntas sobre a relação dele com o coveiro e com Nyembeti. Seu tio Ultímio e seu pai Fulano conseguem liberar Marianinho logo em seguida, e Fulano e Marianinho começam a conversar sobre o ocorrido. Assim, ele descobre que Nyembeti era a única testemunha do assassinato de Juca Sabão. Nesse momento percebemos duas questões importantes, para além dessa revelação: a aproximação de Fulano com o seu filho, e a intervenção de Ultímio por Mariano na prisão. Podemos pensar que dessa maneira, a família já está se unindo, e Marianinho é o elo. Essa questão se fortalece após um acidente que Ultímio sofre, e precisa ficar dentro da Nyumba-Kaya para repousar. É nesse tempo que em uma conversa com Marianinho o seu tio revela que gostaria que Marianinho fosse filho dele. Ele ainda aponta que seus filhos são suspeitos de terem matado Juca Sabão.

Em meio a todos esses pensamentos e evidências, Marianinho finalmente recebe a carta em que seu avô revela todas as questões para que ele possa ser enterrado. Nessa carta Dito Mariano revela que Marianinho é na verdade seu filho com Admirança e também revela questões sobre a morte de Juca Sabão. Assim, ele conta ao filho/neto

Revista Vernáculo n. ${ }^{\circ} 41$ - primeiro semestre /2018

ISSN 2317-4021 
que acha que a arma que matou Juca Sabão na verdade fora de Fulano Malta, e que Dito Mariano havia vendido para seus netos, pois precisava urgentemente de dinheiro. Ao se livrar desse pensamento e se reconhecer como um covarde, Dito Mariano diz ao neto que já pode ser enterrado, e que é para ele pedir ajuda ao coveiro Curozero. O enterro não havia acontecido ainda pois quando tentaram a terra se fechou, o que aponta que era necessário ainda que Dito Mariano pudesse ter esse último assunto com Marianinho para então a terra poder se abrir e ele descansar. Ao finalizar a carta, o avô aponta que só foi possível todo esse movimento de apaziguamento na junção tanto de Dito Mariano com o neto, quanto da própria terra, o próprio lugar com os dois:

Afinal, tudo o que eu escrevi foi por segunda mão. A sua mão, a sua letra, me deu voz. Não foi senão você que redigiu estes manuscritos. E não fui eu que ditei sozinho, foi a voz da terra, o sotaque do rio. O quanto lembrei veio de antes de ter nascido. Como essa estrela já morta que ainda vemos por atraso de luz. Dentro de mim, até já esse brilho esmoreceu. Agora, estou autorizado a ser noite... ${ }^{45}$.

Assim, o que se percebe é que Marianinho conseguiu apaziguar as diferenças que haviam entre os irmãos e avó. Aqui o que vemos é que Mia Couto pensa no apaziguamento através da junção dos diferentes personagens juntos todos dentro da mesma casa a Nyumba- 
Kaya. Marianinhoparte então atrás de Nyembeti que está cavando um túmulo do cemitério.

O livro ainda termina com Marianinho recebendo uma mensagem de seu avô, mas dessa vez ele já não precisava mais escrever. Conseguia entender o que o avô queria lhe dizer, pois já havia se inteirado da tradição, e se tornado capaz de perceber o que seu avô queria lhe dizer. Nesse final, percebemos que Marianinho realmente tornou-se parte de Luar-do-Chãonovamente. O contato que ele faz com Nyembeti ainda criança, demonstra que Mia Couto reforça a ideia de retorno a tradição, já que está é a maior característica de Nyembeti. Marianinho também deixou que a casa entrasse nele e dessa forma, conseguiu cumprir o que o avô havia lhe pedido: apaziguar os conflitos de Luar-do-Chão.

\section{Conclusão}

A partir do posto, pode-se observar que parase estudar a nação moçambicana através de Mia Couto deve ser levado em consideração os diversos processos internos que constituem a história deste país. A literatura é de suma importância para isto, visto que permeia espaços que não são oficiais, permitindo com que o autor possa expressar suas opiniões de forma mais livre, trazendo percepções diferentes sobre o espaço em que vive e auxiliando a pesquisa história. Dessa maneira, essa pesquisa buscou contribuir para a discussão da ideia da nação moçambicana, pensando principalmente a nação de Mia Couto que se 
mostra como algo em construção e de fronteiras fluidas que, que se revelam de maneiras diferentes para as diferentes camadas da população, o que fica bem representado no livro aqui trabalhado. Mia Couto se apresenta como um ser de fronteiras, como apontado anteriormente, e isso se torna notório em seu texto sendo umas das características o neologismo que ele busca inserir em sua narrativa. Isso demonstra que o autor busca mesclar cada vez mais essas diferentes camadas que retrata e confia no papel de cada uma para a construção da nação, sem recorrer a sentimentos nacionalistas (pensando da perspectiva estatal) ou se afastar bruscamente dele, mas sim procurando entender o seu funcionamento e demonstrando a sua constituição histórica. Ele também busca mostrar os diferentes tempos históricos que cada personagem demonstra, cada um retrata os diferentes períodos, desde o jugo colonial, passando pela independência, chegando nos dois momentos pós independência (socialista e neoliberal) e relembrando os períodos de conflitos e guerras que deixaram marcas permanentes na população. Sendo assim, para o autor, é na junção do antigo com o novo, na tradição e na modernidade, nos diferentes tempos históricos que se poderá escrever a história da nação moçambicana.

\section{Bibliografia}

BRAÚNA, J.D. Nyumba-kaya:a delicada escrevência da nação moçambicana na obra de Mia Couto, Fortaleza, 2011

CAHEN, Michel. "Os Outros: Um historiador em Moçambique”, Basel, 1994p. XVI

Revista Vernáculo n. ${ }^{\circ} 41$ - primeiro semestre /2018

ISSN 2317-4021 
CAMPOS, Josilene.S. As representações da Guerra Civil e a Construção da Nação Moçambicana nos Romances de Mia Couto (1992-2000), Goiânia, 2009.

CHARTIER, Roger. Cultura Escrita, Literatura e História. Porto Alegre: Artmed, 2001

COUTO, Mia. Dar tempo ao futuro. E se Obama fosse africano e outras interinvenções. p. 122

COUTO, Mia. Entrevista. In LABAN, Michel. Moçambique: encontro com escritores. Vol. III. Porto: Fund. Eng ${ }^{\circ}$ António de Almeida, 1998, p. 1.033-1.034, APUD Brauna, p.25

COUTO, Mia. Mia Couto e o exercício da humildade. Entrevista concedida a Marilene Felinto. Mundo, Folha de São Paulo. Publicada em 21 de julho de 2002, disponível em: http://www.macua.org/miacouto/MiaCoutoexerciciodahumildade.htm acessado em 30 de novembro de 2015.

COUTO, Mia. Vozes Anoitecidas: Contos. $1^{\circ}$ ed. São Paulo: Companhia das Letras,2013

. A varanda do frangipani. São Paulo: Cia. das Letras, 2007

. Estórias abensonhadas. São Paulo. Cia. Das Letras, 2012.

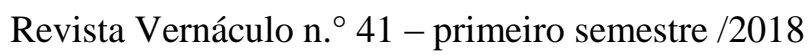

ISSN $2317-4021$ 
. Um rio chamado tempo, uma terra chamada casa. São Paulo:

Cia. Das Letras, 2003

. Venenos de Deus, remédios do diabo. São Paulo: Cia. Das

Letras, 2008

.E se Obama fosse africano e outra interinvenções. São Paulo,

Companhia das Letras, 2011

MACAGNO, Lorenzo. "Fragmentos de uma imaginação nacional”. In;

RBCS, 2009, vol.24, no.70, p.17-35

RICOEUR,P. Tempo e narrativa, Tomo 1. Campinas: papiros, 1994

SARAIVA, Sueli da Silva. A experiência do tempo em dois romances africanos: Um rio chamado tempo, uma casa chamada terra e Mãe, materno mar. Diss. Universidade de São Paulo, 2008.

Recebido em 31/05/2017, aceito para publicação em 16/02/2018

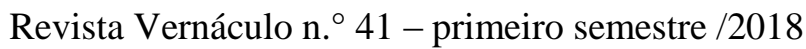

ISSN 2317-4021 